JESSICA DELEANIDES, KEVIN GEBHARDT, JUSTIN HURD, CLAYTON STANLEY

\title{
BIG DATA: CAN IT BE MANAGED? ${ }^{1}$
}

Justin Hurd was confident the answers were in the vast amount of data collected, but how could he best use that data to meet his cost reduction and performance improvement mandate?

Justin Hurd, a regional manager for Marten Transport, Ltd. (Marten), hung up the phone feeling frustrated following a call with his Division VP. The mandate he received was simple--improve operational efficiencies and reduce operational costs. Justin saw his company do amazing things. He saw the company thrive by delivering loads quickly, efficiently and accurately to its customers. They always maintained a good work ethic and honest business practices, even in the face of high stress and publicity. He even saw his company make leaps and bounds in how much technology they utilized, from GPS tracking to data analytics.

However, as he considered his current challenges, he realized that finding and using the data to drive performance improvements was not going to be easy. Justin considered Marten a unique trucking company that stood apart from its competitors. But right now he needed to find the information on where Marten could improve. He contacted Marten's Vice President of IT, Randy Baier to see what performance data was already collected. Randy informed him that by utilizing telematics to include ID Systems and StarTrak devices, Marten could monitor reefer settings and performance as well as trailer positions to uncover possible trailer abuse or operating inefficiencies. The data collected so far, identified clear inefficiencies, and indicated possible abuse by warehouse operators at Marten’s expense.

The challenge any firm faced with a big data problem was determining how they would convert relevant data into useful information. Because of the exponential rate at which data was produced, companies must practice ingenuity by proposing specific operations, and focusing their data gathering efforts on what they needed and what they could use.

Marten's data gathering initiative had produced a wealth of information related to these issues, but how could this data be transformed into useful, actionable metrics that could reduce these inefficiencies and protect Marten's bottom line? Was more data needed? If so, what kind of data and how should it be collected? Were there other technological control measures that could be applied by Marten to mitigate the impacts of their current issues? Surely other leading transport companies were facing similar issues. Perhaps there were existing solutions being implemented, but would they work for Marten? Justin Hurd was confident the answers were in the vast amount of data collected, but how could he best use that data to meet his cost reduction and performance improvement mandate?

\footnotetext{
${ }^{1}$ Copyright $(0)$ 2016, Muma Case Review. This case was prepared for the purpose of class discussion, and not to illustrate the effective or ineffective handling of an administrative situation. Names and some information have been disguised. This case is published under a Creative Commons BY-NC license. Permission is granted to copy and distribute this case for non-commercial purposes, in both printed and electronic formats.
} 


\section{Industry Background}

\section{Origins}

The trucking industry could be traced back to the early 1900s, as American industry expanded throughout the nation. In a consumer-driven economy, the transportation of goods was critical in the supply chain. From 1869 until the 1920s, the Transcontinental Railroad was the primary way businesses transported their goods across the country. Moving into the early 1920s and 1930s, business owners began shipping and delivering goods by truck (Tyler, 2014). In 1935, the Interstate Commerce Commission (ICC) began regulating motor carrier rates, causing very little competition in the industry, thus leading to inefficiencies (see Exhibit 1).

\section{Deregulation and Competition}

1980 was a benchmark year in the trucking industry. Jimmy Carter signed The Motor Carrier Act (see Exhibit 1) that would eliminate restrictions on commodities that could be carried, routes that motor carriers could use, and geographical regions that they could serve (Moore, 1993). As a result, many large trucking companies failed because of revealed inefficiencies in their spending and operations in an unregulated industry.

Companies that thrived were those that capitalized on saving delivery costs and strategically expanding their territories. Truck drivers no longer had to seek authority to carry goods into a particular geographical area. Before deregulation, truck drivers were required to seek authorization to carry a load, however, it may not have been authorized to carry a different material on the return trip and therefore, would return empty. When deregulation occurred, companies that could decrease these delivery costs became extremely competitive. Cutting costs and increasing efficiencies continued to be the trend in trucking company successes.

\section{Operations}

Trucking operations were categorized in a variety of ways. Companies were either private or public, also called "for-hire." A private fleet was owned by the company it serviced. Common examples of private fleets would be grocery stores and retail chains ("Trucking Industry Overview," 2014). These fleets contributed to the companies' overall costs and bottom line. For-hire companies provided transportation services for others. For-hire companies would provide an array of services, and would be evaluated based on capacity, operating areas, services, certifications and vertical specialties (see Exhibit 3). Their revenues were increased by continued expansion and by growth of client bases. Profits were increased by increasing efficiencies and cutting costs.

The national average fleet size (capacity) was 3,268 trucks, with 71\% operating in all of North America, $84 \%$ of companies offering truck load (TL) services, and 85\% of companies specializing in transporting "freight of all kinds" (O'Reilly, 2014).

The most common trucking services were less than truckload (LTL) services, shipments of loose freight, and truck load (TL) services via shipments in sealed containers. Seventy-one percent of companies operated in all of North America, with 28\% operating in the U.S alone and 38\% operating globally. These two factors played an especially large role in the for-hire company's ability to generate revenue.

\section{Marten Transport Background}

Marten Transport was a leading transportation provider of time and temperature sensitive commodities throughout North America. It had its beginnings in 1946, as founder Roger Marten at the age of 17 started 
the enterprise as a small milk and dairy product delivery service for Modena Co-Op Creamery in his hometown of Modena, Wisconsin. Throughout the 50's, 60's, and 70's Marten continued to slowly grow and expand through acquisitions of other small carriers, while it purchased new regulated interstate lanes to grow and service customers throughout the Midwest, West Coast, and Southeast, and developed and built a home terminal in Mondovi, Wisconsin. In 1976, there was a major change when Marten purchased Hiawatha Produce, which started a transition of the company into its current niche as a long-distance hauler of perishable foods in refrigerated trailers.

Marten specialized in providing full truckload, irregular route carrier services across 48 states, Canada and Mexico, as well as long haul and multi-faceted temperature control carrier services. Marten strived to be the premium supplier of time and temperature-sensitive transportation services to customers nationwide, serving customers with more demanding delivery deadlines, as well as those who shipped products requiring modern temperature controlled trailers to protect goods. Critical to Marten's business model was quality of service, on-time delivery and quick-to-market operations.

In 1979, through the stroke of his pen, U.S. President Jimmy Carter changed the trucking industry forever with the Motor Carrier Act of 1980. According to the President,

This is historic legislation. It will remove 45 years of excessive and inflationary Government restrictions and red tape. It will have a powerful anti-inflationary effect, reducing consumer costs by as much as $\$ 8$ billion each year. By ending wasteful practices, it will conserve annually hundreds of millions of gallons of precious fuel. All the citizens of our Nation will benefit from this legislation. Consumers will benefit, because almost every product we purchase has been shipped by truck, and outmoded regulations have inflated the prices that each one of us must pay. The shippers who use trucking will benefit as new service and price options appear. Labor will benefit from increased job opportunities. And the trucking industry itself will benefit from greater flexibility and new opportunities for innovation. (White House Press Release).

By eliminating barriers to entry, the number of licensed carriers doubled to over 40,000 by 1990, which greatly increased competition between firms. This change of regulation allowed Marten to rapidly expand its customer base to include many Fortune 500 companies such as Anheuser-Busch, Coors, Proctor and Gamble, Pillsbury, Kraft and 3M. With this national expansion in 1985, Marten added service centers in Southern California, Oregon, and Georgia to perform maintenance on its equipment while out in the field.

The next few years brought continuous change at Marten Transport, as the company went public on the NASDAQ in 1986, with an IPO of \$13 per share. The same year, with Roger’s son Randy Marten as President of the company, Marten posted gross revenues in excess of \$50 million. In 1993, founder Roger Marten passed away and Randy became CEO of the company.

Since 2000, Marten had continued to grow and diversify its business model. In 2004, the corporate office received an 11,000 square foot addition, and a new service facility was opened in Indianapolis. A year later in 2005, Marten opened two logistic services departments including its own brokerage firm and an intermodal department, both of which helped to provide capacity to Marten's existing customer base, while at the same time maintained Marten's competitive pricing. Through the 2008-2009 recession, Marten continued to show a profit while many competitors posted losses, and others were forced to leave the industry. At the same time, Marten continued to expand its footprint by opening two new service centers, and beginning door to door service to customers that had business in Mexico. By 2010, Marten opened an additional 5 service centers in Florida, Pennsylvania, Arizona, Kansas and Tennessee. These 
additional service facilities helped decentralize Marten's operations from a corporate hub model to a regional platform that allowed each facility's operations personnel to be in closer contact with drivers and customers.

Throughout its history, Marten Transport was an industry leader in profitability, growth and innovation. By 2013, Marten had grown to over 3000 employees, and reported the highest net income for any year in its history (see Exhibit 5). For the year ending December 31, 2013, gross income was $\$ 659.2$ million, while net income improved $10.6 \%$ to a record \$30.1 million (“Marten Transport,” 2014).

Over this period, Marten was in the Forbes "200 Top Small Companies” list twice and named one of Forbes “America's 100 Most Trustworthy Companies” four of the last five years. Marten was also a partner of the EPA's Smartway Transport program due to its efforts to reduce emissions by installing auxiliary power units on its tractors along with reducing its total hours of reefer usage. This was accomplished by working with customers to raise the temperature on frozen loads from the industry standard of -10 to -1 without compromising product integrity. And Marten was a certified "Top Pay Carrier” for drivers--historically a big factor for driver retention and company growth.

\section{Current Issues}

Marten had done well with implementation of technology up to this point. They started with Qualcomm, the most current technology of its time, and then switched to OmniTracs MCP200 after identifying competitive advantages. They purchased StarTrak systems from OmniTracs, and saved millions by increasing efficiencies of their refrigerated units. But Justin wondered how Marten could effectively utilize such a large amount of data. Was the current data sufficient to address the issue of reefer cost reduction, or was more needed?

\section{Captured Data}

The trucking industry as a whole had focused much of their technology on improving efficiencies and had made no effort to hide it. When Kyle Mayo, Knight Transportation's service center manager in Lakeland FL, was asked what additional technologies he thought would enhance efficiency within the industry, his response was, "Anything that can help the driver."

Marten attempted to have its drivers deliver one loaded trailer at a customer location, pick up a preloaded trailer, and then have that driver continue to the next location. The idea was to save payroll because the wait time of the driver would be reduced. While improved routing and determining fuel stop points obviously cut costs for one entity, it may have increased a cost elsewhere within Marten's financials.

As Vice President of Information Systems, Randy Baier was very knowledgeable on the information that OmniTracs MCP200 and StarTrak provided to the company. He believed that data mining and analytics was the key to improving efficiencies within the industry. As he explained it, "We have tons of data within our reach. We just need to use it.”

\section{Data Collection Devices}

Advancements in information technology were the next phase of increased competition within trucking. As early as 1986, larger companies began installing two-way satellite communication and computer dispatching systems in their operations. These technologies became affordable in the 1990s (Kettinger, Patel, \& Ryoo, 2012).

Trucks became equipped with Electronic Onboard Recording Devices (EORD) (see Exhibit 4). EORDs recorded driving hours, monitored duty status, short idling time, long idling time, miles per gallon, excess 
speed, and log in and log out times, among other parameters (Kettinger, et al., 2012). These data were then transmitted to operation managers for data analysis. It was not until 2002 that mainstream trucking companies began to invest in logistics software and technology as a way to use the data to reduce costs (“Trucking Industry Overview,” 2014).

A decade later, other technologies such as mobile communication and Wi-Fi, contributed to increased efficiency in communication. No longer did drivers have to pull over to call operation centers to report a breakdown or emergency, they would now be able to communicate from the road. Also, global positioning systems (GPS) enhanced tracking of fleets. Route selection, scheduling and intermodal coordination became more efficient, and "just-in-time" with the ability to track locations of trucks, traffic and other modes of transport.

\section{Continuous Data Collection through Mobile Tracking}

In 1993, Marten began to implement a new tracking and communications device called Qualcomm in all of its tractors. It was a simple satellite unit that, through GPS technology, provided real time position tracking, communication of load information, and acted as a portal from the driver of the tractor back to operations. This system, while basic when compared to today's standards, was ahead of its time in a communications era where cell phone ownership was not widespread, and as compared to prior methods of daily scheduled check-in phone calls. As new software was introduced, Marten upgraded its Qualcomm package to track engine performance, fuel mileage, driver idle time usage and critical event reporting which recorded driving habits in order to help identify potential drivers at risk for future accidents.

At the time of the case, Marten used the OmniTracs MCP 200 platform. It had all the features of the older style Qualcomms, but ran off terrestrial cell towers instead of satellites. The new unit was a color touch screen, and included a company approved GPS routing system, web browser, a media player for company safety messages, a scanner for the driver to turn in paperwork, and electronically managed the driver's DOT regulated logbook.

Since Marten specialized in refrigerated transportation, in 2008 it completed the installation of the StarTrak devices on all of its trailers. These devices provided real time information to monitor temperature settings, reefer performance, trailer location and fuel level monitoring. These systems were created to attempt to eliminate costly claims related issues due to spoilage from inaccurate temperature settings, mechanical breakdown on the reefer units, and running out of fuel while loaded. These devices have saved Marten millions of dollars since installation, and were a critical part of daily operations.

\section{Data Reporting}

In the temperature-controlled freight industry, the end of the summer marked the beginning of "candy season." Many of the confectionary industry heavy-weights geared-up to ship thirty to forty percent of their annual volume in a two-month period, in preparation for the Halloween holiday. This time frame also marked many new-product launches within the candy industry, and it was not uncommon for many marketing executives to become engaged with their supply chains. This level of demand made it very challenging for any carrier to meet its capacity commitment to confectionary customers, while still satisfying demand from its other customers.

August of 2013 marked another prelude to candy season, but the much-increased demand for capacity throughout the year, along with newly-made commitments to M\&M-Mars would change the way Marten 
evaluated customer relationships, and the way it tracked trailer utilization. Newly added commitments from a production facility in Joliet, IL shipping to a distribution center in Kennesaw, GA, along with commitments from Cleveland, TN to a distribution center in Romeoville, IL would set the stage for a showdown between the two companies. As the last week of August was coming to a close, recent activity within Marten Transport revealed approximately 27 trailers stock-piled, and inbound loaded in Kennesaw, with an additional 32 in Romeoville, IL. Upon further examination, with the use of telematics on Marten Trailers, many of these trailers had been sitting for 5-6 days, running at 35 degrees, and burning up the 75 gallons of diesel fuel per trailer--only to be refilled by each distribution center, so they could continue to run even longer.

In Kennesaw, Georgia, the Area Sales Director was asked to visit the site and evaluate the issue as to why the receivers were not unloading the equipment. Kennesaw was a third-party warehouse facility, so the managers on-site were not actual Mars employees, which made it very easy to assess the source of the issues. The meeting revealed that there was sufficient labor to unload the trailers, and sufficient warehouse capacity. Mars was simply not ordering the trailers to be unloaded due to cost. The contracted rate of four days free, followed by a charge of \$50 per trailer, per day excluding weekends, was far less than warehousing labor and storage rates. After these discussions in Kennesaw, Marten Transport immediately stopped accepting all load tenders from production facilities into Kennesaw, GA and Romeoville, IL. At the same time, sales executives throughout Marten reached out to corresponding supply-chain managers at Mars, but were not met with any real answers.

After a little over a week, significant supply-chain issues had arisen within Mars, and top Mars executives now wanted to know why one of its major truckload carriers had decided to stop meeting its agreements with the massive confectionary shipper. The pipeline for distribution within Mars had been seriously disrupted, and Mars wanted answers. A conference call with executives between Mars and Marten transpired, and at its conclusion, Mars executives stated: "We don't care about your trailer issue. That is your business; we are in the business of getting our candy to market.” Marten Transport's response was simple: "If you will continue to abuse our relationship, we don't care about getting your candy to market.” This call would terminate the relationship between the two companies. Additionally, a trailer utilization report was established, recognizing which customers would not unload Marten equipment, and which were impacting Marten's profits through improper use and excessive consumption of diesel fuel in its reefer tanks.

Marten would follow candy season 2013, and the dissolved relationship with Mars with two recordquarters in terms of revenue and profit. Marten's “Trailer Dwell Report” would be renamed, “The Mars Report.”

\section{The Future of IT in Trucking}

The new advancements in trucking technology had attracted companies because of their proven inherent ability to decrease costs. These costs were mostly associated with the trucks themselves--how long were they on the road, how much fuel they were using, how long they remained idle at a stop, etc. (see Exhibit 2). EORDs delivered huge amounts of data to operation managers daily, only some of which was mined to glean important information. Nonetheless, it had taken almost 20 years after the EORD became affordable before business analysts began to leverage this data on a larger scale to make decisions and form projections.

As a company Marten thrived after the 1980 Motor Carrier Legislation, and after two decades of expansion and growth, diversified its business model to include intermodal transportation. Marten had maintained competitive pricing to its clients, provided top speed and efficiency in its delivery, and stayed on the edge of innovation--making it a top transport company in the industry. 
In a survey done on roughly 3,000 managers and analysts, MIT Sloan Management Review and IBM Institute for Business Value discovered that the top performing firms used analytics five times more frequently than the lower performers. Marten had an outstanding track record within the industry, but how did their analytical skills compare to the industry? How could they improve?

Marten had always maintained fair business practices, even after seeing their relationship abused by some customers, such as Mars. This kind of philosophy never hindered its performance; in fact, it enhanced their ability to thrive. Marten did not hesitate to embrace the Qualcomm tracking device as soon as it became affordable, and upgraded at every opportunity. They received data on metrics such as idling, speed, RPM, coasting out of gear, fuel consumption, engine time and distance traveled. They also received safety reports on hard breaking deceleration rates, parking break status, trucker positions and locations. Most recently and most notably, they developed and embraced trailer utilization reports. Dozens of metrics and reports on hundreds of trucks appeared in Justin Hurd's inbox every day.

Justin asked himself: How could he use the data generated to answer the questions he had and to identify the true inefficiencies? Was all data good data? What data feeds would the reports generate? How massive was this big data?

\section{Unidentified Data}

The technology within the industry allowed transportation companies to capture data points of trailers including: whether trailers were loaded or unloaded, if they were running or not running, and what the temperatures were in various areas of the trailer. These data points were available through Qualcomm; however, they were not available through OmniTracs' StarTrak.

Qualcomm would display a warning across the screen when the temperature fell out of the five-degree standard. They may have also questioned the warehouse or customer as to why their reefers were running while their trucks were not unloaded. Many warehouses did not store the contents of reefer trailers, and left Marten's trailers running outside. Because of this misuse, Marten had recognized increased fuel usage during the summer months.

The trucking industry had always monitored weather as part of the decision making process. Most companies within the industry based operational decisions on current and forecasted weather patterns. Weather was often unpredictable and could not be controlled, but variables affecting costs and operations that could be influenced were their customers and warehouses.

Just as transportation management systems (TMS) were utilized by Marten, Knight, and their competitors, warehouse management systems (WMS) were utilized by many customers. Marten provided some feedback from its TMS, but for the most part, they received very little feedback from the warehouses. If Marten were able to increase communication with its customers, what information could be provided between the two industries to help Marten with their IT issues, specifically keeping warehouses from abusing their reefer trailers, and driving up Marten’s fuel costs?

\section{Big Data}

Marten had technology in place which provided crucial information that could lead to a reduction of inefficiencies. However, the enormous volume of data available presented Marten with a big data dilemma. 
Big data was defined as being "too voluminous or too unstructured to be managed and analyzed through traditional means" ("How 'Big Data' is Different," 2012). The idea that effective management of big data could unlock new organizational competencies was a common belief in business that continued to build momentum. While the data provided in years prior may have been manageable, Marten was at the point of gathering too much data to be examined by old fashioned analytics. The sheer magnitude of big data collected by Marten's monitoring devices was staggering. For example, within a six week time period, Marten gathered information on 13,403 loads, including the number of loads over 12 hours, average run time, and the sum of those costs. Examples of how this data was captured and presented are illustrated in Exhibit 6: Marten Data Collection.

Marten had been using information provided to them by their truck and trailer tracking systems, and had already identified one Walmart distribution center as being a major offender of reefer run times compared to others. Could appropriate analytics continue to improve their performance in the future? Justin thought a closer look at reefer times, and costs to identify the smallest offending customers that Marten had, might have been a start. With this data, Marten could identify peak seasons for those customers, and work on securing more loads from those same customers.

Justin was not very knowledgeable of where in Marten's operations current information systems were being utilized, or where data was being stored. He just knew the reports he received--not the data, or data collection processes behind them. He did know however, that the same reports he received each week were identifying several choices he needed to make about where to affect change.

\section{The Decision}

Justin started to look at his fuel expense line for the last few years to identify patterns and trends. Tractor fuel was mostly flat and based on truck counts. Reefer trailer fuel however, always spiked during the months of summer because higher temperatures influenced the refrigeration energy expenditure, but this did not account for all of the cost. Typically, the trailers were only turned on when loaded, but that was only when drivers live-loaded and unloaded at a delivery stop, and used the same trailer for an entire trip.

Justin wondered if trailers were turned on in the same manner when Marten pre-positioned equipment at customer locations, so the customers could pre-load trailers, preventing Marten drivers from having to wait for live-loading. Pre-positioning saved drivers a lot of time, allowing them to haul more loads, and it was good for business. But was that efficiency being countered by customer actions? When were the customers turning on the reefers and for how long? Were customers running trailers excessively before the pickup appointment? How much refer fuel was expended per hour on cooling a trailer in the middle of summer?

The same excessive costs could be occurring when Marten drivers delivered loaded trailers to a customer, and then left with an empty trailer without waiting for the trailer unload. How long did the trailer sit running until the customer unloaded it? Once unloaded, was the customer shutting the trailer off? Justin looked at the trailer pools at some of his larger customers, and noticed some trailers had not moved for a couple of weeks. What was happening with those trailers? Justin began to think reefer fuel was a solid cost reduction target to focus on, but how could he get the data he needed to verify his theory? And once obtained, how could that data be used to effectively reduce costs for Marten?

Performance, efficiency and innovation carried Marten to the top, but with the inflow of massive amounts of data--how could they sift through it all to gain the right analytics to stay on top?

Justin contemplated how to put together his plan of action to present to his Division VP. He had identified reefer fuel costs as a target area for cost reduction. He also discovered that an enormous amount of 
information had been collected by Marten's existing technology, supporting his theory that there were cost inefficiencies, and possible abuse by customers involving Marten's reefer trailers. Justin knew the core issue at hand was how Marten could transform this large amount of collected data into useful, actionable metrics that could be used to reduce the identified cost inefficiencies and protect Marten's bottom line. Justin considered his options.

\section{Existing Data}

Marten could use the data already collected through current telematics systems to identify specific metrics showing the exact points of reefer runtime that were unnecessary. The same data could also be used to identify runtimes initiated by customers outside of Marten's knowledge. Marten could then approach offending customers to reduce or stop that type of runtime, or if determined as necessary, adjust their contracts with those offending customers to receive compensation. Existing data could also likely be analyzed for other potential cost efficiencies beyond reefer runtimes. Justin thought it very possible that potential cost reduction efficiencies were being overlooked because of a narrow focus on this single issue. Expanding the analysis of existing data would certainly be a low-risk method from a cost perspective as far as the data was concerned, but changing customer behavior might not be so easy.

\section{New or Additional Data}

A more effective action for Marten could be to focus on filling the current holes in the existing data available by modifying the type of data collected, and the way it was collected via Marten's telematics systems. It was possible that Marten had not been utilizing its current technology in the best way to maximize the use of the data they collected. If the possibility existed that Marten was not utilizing all of the existing data to its maximum potential, it was also possible that Marten's current technology was not being used to its maximum potential to net new additional data. If the technology could be applied to identify specific metrics for trailers while at customer warehouses, that could provide evidence and substantiation for Marten's claims of abuse. Maybe, there would be enough leverage to influence a change in customer behavior. Justin thought an adjustment to the type of data Marten collected, as well as an adjustment to the way it was collected using existing systems might be a low risk, low cost option for realizing cost savings across the board.

\section{New Technology}

Justin considered the possibility that Marten's current technology simply wasn't suited for solving the issue of cost reduction, specifically concerning reefer fuel usage and customer abuse. After speaking with Randy, Marten’s VP of IT, there definitely seemed to be a focus on GPS technology and tracking Marten driver actions more than the actions of Marten customers. Perhaps newer cutting-edge industry technology was what Marten needed to achieve the desired cost reductions. Justin wasn't sure what upfront costs would be involved in acquiring and implementing new technology targeted at this specific issue, or if Marten's IT group had the knowledge and ability to implement the new technology if it was acquired. But, if successful, the cost savings benefit of the new technology might make the up-front investment well worth it.

\section{Outside/Consultant Help}

Another thought occurred to Justin. Maybe the bigger problem for Marten was not collecting more or different data. It may be that Marten could benefit most from assistance in determining the root causes of their issues through a detailed analysis. Justin knew from experience that it could often be difficult for 
people to be objectively critical of their own work or processes. A review and analysis of their operating processes and procedures, specifically regarding their use and the application of currently owned technology might be of great benefit. Maybe if the review was conducted by an outside group of industry consultants, they might be able to better isolate the root causes of the cost inefficiencies, and help with recommendations for new technology, or better usage of existing technologies. This however, could carry an estimated cost between $\$ 14,000$ and $\$ 27,000$. Would this up-front cost be more than Marten’s executive leadership was willing to spend?

\section{Do Nothing?}

As Justin ran through these decision options, and the challenges associated with each, he began to wonder if it was necessary to add anything new to what was already being done. Marten had already realized some fairly significant cost savings from the data analysis conducted up to this point. It was probably a safe assumption that a continued steady-state reduction in costs could be achieved through this previously conducted analysis. Justin also thought he could find further efficiencies that realized cost savings by having his drivers change their behaviors to provide him feedback on identified cost reduction areas after each run. Justin was a people-person, and found it much easier to interact with his drivers to achieve results. He was not overly confident in the cost reduction outcomes that could be achieved through data collection and mining alone.

Justin had some decisions to make before he could make his recommendation to his Division VP. He was certain he had all the pieces to the puzzle, now he just had to put them together.

\section{References}

Comprehensive truck size and weight (CTS\&W) study. (2011). Retrieved from https://www.fhwa.dot.gov/reports/tswstudy/Vol2-Chapter3.pdf

Davenport, T. H., Barth, P., \& Bean, R. (2012). How big data is different. MIT Sloan Management Review, 54(1), 43.

Harps, L. H. (2004, September). The transformation of truck transportation. Inbound Logistics. Retrieved from https://trid.trb.org/view.aspx?id=738735

Kettinger, W., Patel, J., \& Ryoo, S. (2012, June 1). The role of information technology in causing and reducing truck driver stress and its relationship to turnover. Retrieved from http://www.memphis.edu/ifti/pdfs/cifts_truck_driver_stress.pdf

Moore, T. G. (1993). Trucking deregulation. The Concise Encyclopedia of Economics. Retrieved from http://www.econlib.org/library/Enc1/TruckingDeregulation.html

O'Reilly, J. (2014, September). 2014 Trucking perspectives. Inbound Logistics. Retrieved from http://www.inboundlogistics.com/cms/article/2014-trucking-perspectives/

Schultz, J. (2012, April 12). Top 50 trucking companies: Strongest get smarter. Retrieved from http://www.logisticsmgmt.com/article/top_50 trucking_companies strongest get smarter

Trucking industry overview - complete version. (2014, February 13). Retrieved from http://www.irs.gov/Businesses/Trucking-Industry-Overview---Complete-Version\#3

Tyler, G. (2014). History of freight transportation. Retrieved from http://www.sourceconsulting.com/history-of-freight-transportation/ 


\section{Biographies}

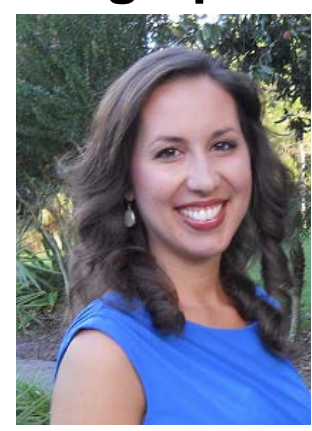

Jessica Deleanides is an MBA student at the University of South Florida in Tampa, FL. She earned a Bachelor's of Arts degree in International Studies from the University of South Florida in 2009. She currently works in education and career development while pursuing her MBA.

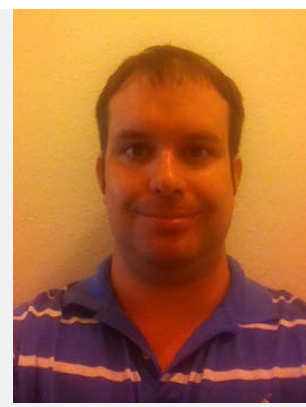

Justin Hurd is the Regional Operations Manager for Marten Transport. He regularly identifies gaps in performance, operational compliance and adherence to established protocols. He started his MBA program at the University of South Florida in July of 2013 with an anticipated graduation in the fall of 2016.

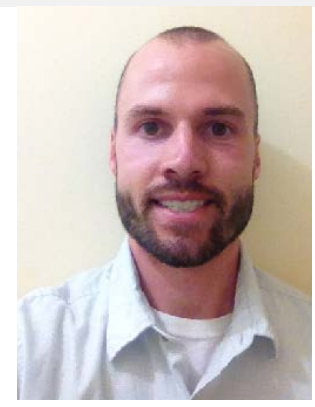

Kevin Gebhardt is a Department Manager for Lowe's Home Improvement. He manages inventory and staffing in two departments, as well as controlling pricing and running sales events. He received his Bachelors in Business Administration at the State University of New York Institute of Technology in Rome, New York. Kevin was previously a Sales Manager for Bridgestone tires.

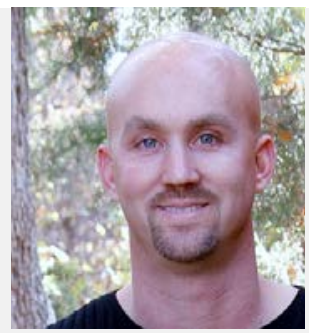

Clay Stanley is Group Leader, Proposals for CAE USA, an Aerospace \& Defense Simulation company. He leads a team of proposal managers, cost \& price estimators, writers and editors in the planning, development, validation and delivery of compliant bids and proposals. Clay is a combat veteran with over 10 years as an officer in the US Army. 


\section{Exhibit 1: Early Timeline of Trucking Industry}

\begin{tabular}{|c|l|}
\hline Date & \multicolumn{1}{|c|}{ Event } \\
\hline Late & The Federal Government began regulating transportation companies to prevent railroads \\
1800 's from charging unfair freight rates. Regulation also helped to protect transportation companies \\
from unfair competition.
\end{tabular}

Source: Trucking industry overview - complete version. (2014, February 13). Retrieved from http://www.irs.gov/Businesses/Trucking-Industry-Overview---Complete-Version\#3 


\section{Exhibit 2: Greatest Challenges of Trucking Companies}

FIGURE 1 Greatest Challenges

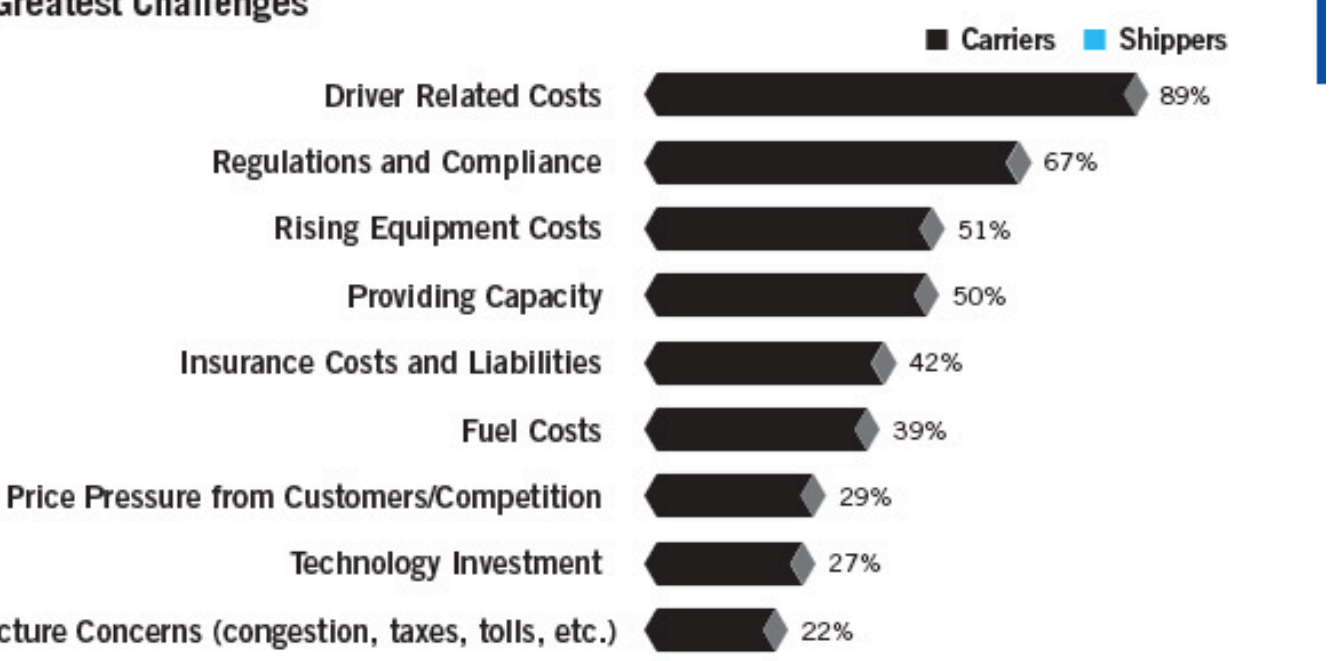

Source: O'Reilly, J. (2014, September). 2014 Trucking perspectives. Inbound Logistics. Retrieved from http://www.inboundlogistics.com/cms/article/2014-trucking-perspectives/ 


\section{Exhibit 3: Overview of Trucking Specialties}

\section{FROM THE DRIVER'S SEAT}

The U.S. trucking industry provides an array of services, from mud-flapping nationwide truckload shipments to white-glove, last-mile delivery-and everything in between. Here's an overview of carrier services, geographic scope, and assets based on Trucking Perspectives survey responses.

CAPACITY
Average Fleet Size (tractors and
Average Trailer Fleet
Average Number of Drivers (ow
included)
OPERATING AREA
North America
U.S. Only
Global
TRUCKING SERVICES
Truckload
Logistics Services
LTL
Dedicated Contract Carriage
Expedited

CAPACITY 6,840 units

rators 2,867 drivers

Intermodal

Refrigerated

Flatbed

Final Mile

White Glove

Bulk

71\% Household Goods

$29 \%$ Motor Vehicle Carrier

$38 \%$ Tanker

Package

$84 \%$ CERTIFICATIONS

$73 \% \quad$ SmartWay

$59 \%$ HazMat

$58 \%$ C-TPAT

$55 \%$ Free And Secure Trade (FAST)

ISO

$\begin{array}{rlr}47 \% & \text { Partners In Protection (PIP) } & 29 \% \\ 41 \% & \text { ACC Responsible Care } & 19 \% \\ 40 \% & \text { Six Sigma } & 2 \% \\ 31 \% & \text { Lean } & 2 \% \\ 27 \% & & \\ 26 \% & \text { VERTICAL SPECIALTY } & \\ 18 \% & \text { Freight All Kinds } & 85 \% \\ 14 \% & \text { Retail } & 74 \% \\ 16 \% & \text { Food \& Beverage } & 74 \% \\ 9 \% & \text { Construction \& Building Materials } & 70 \% \\ & \text { Automotive } & 68 \% \\ & \text { Chemicals } & 61 \% \\ 89 \% & \text { High-Value (electronics, pharma, jewelry) } & 61 \% \\ 75 \% & \text { Agriculture } & 55 \% \\ 60 \% & \text { Furniture } & 54 \% \\ 40 \% & \text { Oil \& Gas } & 36 \% \\ 31 \% & & \end{array}$

Source: O'Reilly, J. (2014, September). 2014 Trucking perspectives. Inbound Logistics. Retrieved from http://www.inboundlogistics.com/cms/article/2014-trucking-perspectives/ 


\section{Exhibit 4: Electronic Onboard Recording Devices (EORDs)}
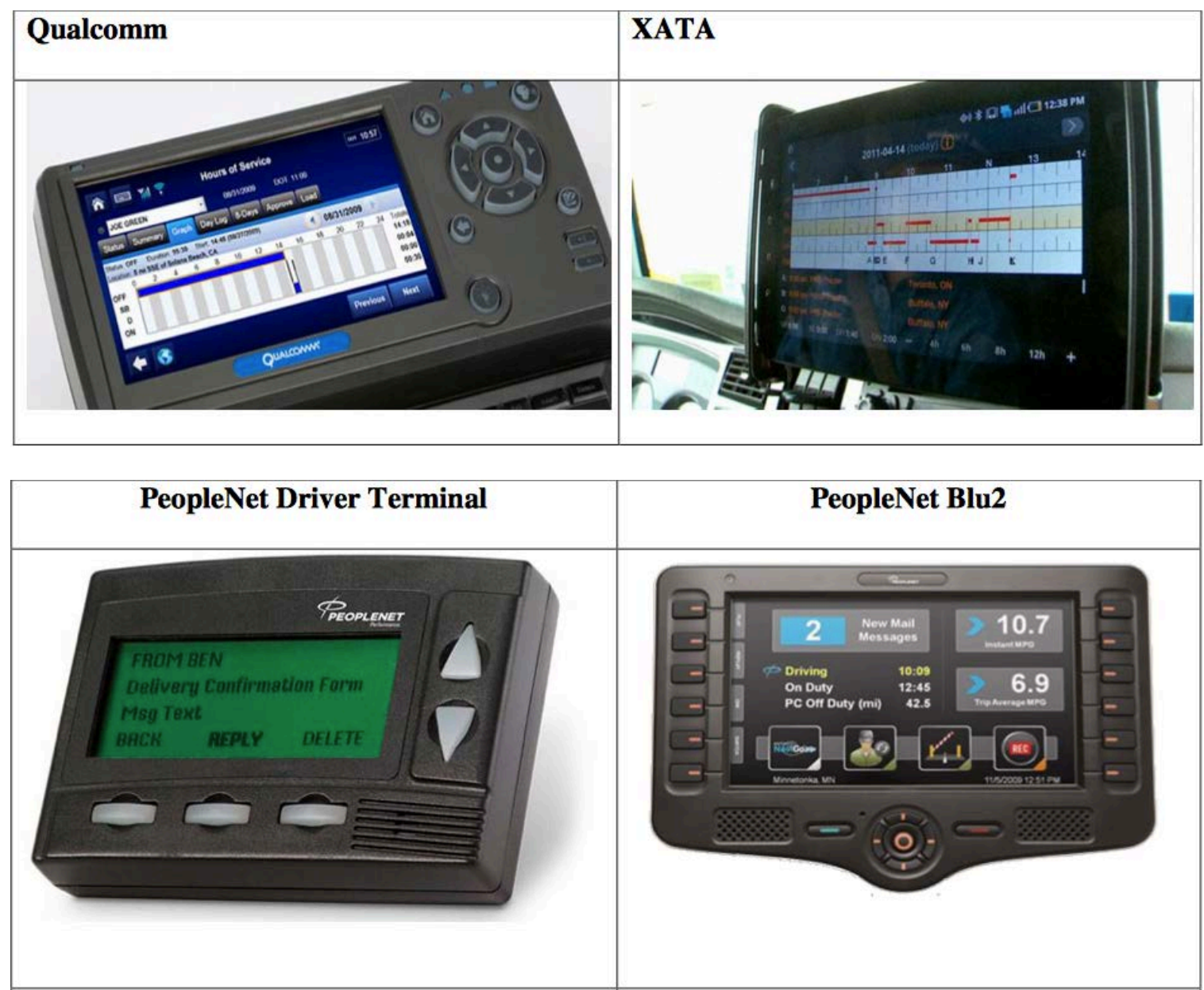

Source: Kettinger, W., Patel, J., \& Ryoo, S. (2012, June 1). The role of information technology in causing and reducing truck driver stress and its relationship to turnover. Retrieved from http://www.memphis.edu/ifti/pdfs/cifts_truck_driver_stress.pdf 
Exhibit 5: Marten's Ratings

\begin{tabular}{|c|c|c|c|c|c|c|c|}
\hline $\begin{array}{l}2013 \\
\text { Rank }\end{array}$ & Parent Company & $\begin{array}{l}\text { Primary } \\
\text { Service }\end{array}$ & $\begin{array}{l}\text { Subsidlary Portfollo / Services } \\
\text { \& Comments }\end{array}$ & $\begin{array}{l}\text { Publlel } \\
\text { Private }\end{array}$ & $\begin{array}{l}2012 \text { Annual } \\
\text { Revenue } \\
\text { (In millions } \\
\text { of dollars) }\end{array}$ & $\begin{array}{l}2013 \text { Annual } \\
\text { Revenue } \\
\text { (In millions } \\
\text { of dollars) }\end{array}$ & $\begin{array}{c}\text { 2012-2013 } \\
\text { Percent } \\
\text { Change }\end{array}$ \\
\hline
\end{tabular}

\begin{tabular}{|c|c|c|c|c|c|c|c|}
\hline 25 & $\begin{array}{l}\text { Southeastern Freight } \\
\text { Lines }\end{array}$ & LTL & Southeastern Freight Lines & Private & $\$ 875$ & $\$ 914$ & $4.5 \%$ \\
\hline 26 & $\begin{array}{l}\text { Universal Truckload } \\
\text { Services }\end{array}$ & TL & Merged with Linc Logistics in Oct. 2012 & Public & $\$ 758$ & $\$ 828$ & $9.3 \%$ \\
\hline 27 & Quality Distribution & $\mathrm{TL}$ & $\begin{array}{l}\text { Energy Logistics division was largest } \\
\text { contributor to revenue growth due to } \\
\text { acquisitions in } 2012\end{array}$ & Public & $\$ 721$ & $\$ 800$ & $11.0 \%$ \\
\hline 28 & Trimac Group & $\mathrm{TL}$ & Acquired three companies in 2012 & Public & $\$ 709$ & $\$ 761$ & $7.2 \%$ \\
\hline 29 & $\begin{array}{l}\text { Ruan Transportation } \\
\text { Management Services }\end{array}$ & TL & $\begin{array}{l}\text { Dedicated Contract Carriage, Bulk } \\
\text { Transportation }\end{array}$ & Private & $\$ 708$ & $\$ 735$ & $3.9 \%$ \\
\hline 30 & $\underline{N F I}$ Industries & $\mathrm{TL}$ & Dedicated, Intermodal & Private & $\$ 634$ & $\$ 717$ & $13.1 \%$ \\
\hline 31 & Ryder System & $\mathrm{TL}$ & Dedicated Contract Carriage & Public & $\$ 665$ & $\$ 709$ & $6.6 \%$ \\
\hline 32 & $\begin{array}{l}\text { Covenant Transportation } \\
\text { Group }\end{array}$ & TL & $\begin{array}{l}\text { Covenant Transport, SRT, Star } \\
\text { Transportation }\end{array}$ & Public & $\$ 674$ & $\$ 685$ & $1.5 \%$ \\
\hline 33 & Celadon Group* & $\mathrm{TL}$ & Acquired 9 companies in 2013 & Public & $\$ 612$ & $\$ 681$ & $11.2 \%$ \\
\hline 34 & Marten Transport & $\mathrm{TL}$ & Truckload, Intermodal & Public & $\$ 608$ & $\$ 653$ & $7.4 \%$ \\
\hline 35 & Stevens Transport & TL & $\begin{array}{l}\text { Temperature-Controlled Truckload, } \\
\text { Intermodal }\end{array}$ & Private & $\$ 609$ & $\$ 621$ & $2.0 \%$ \\
\hline
\end{tabular}

Source: Schultz, J. (2012, April 12). Top 50 trucking companies: Strongest get smarter. Retrieved from http://www.logisticsmgmt.com/article/top 50 trucking_companies strongest_get smarter 
Exhibit 6: Marten Data Collection

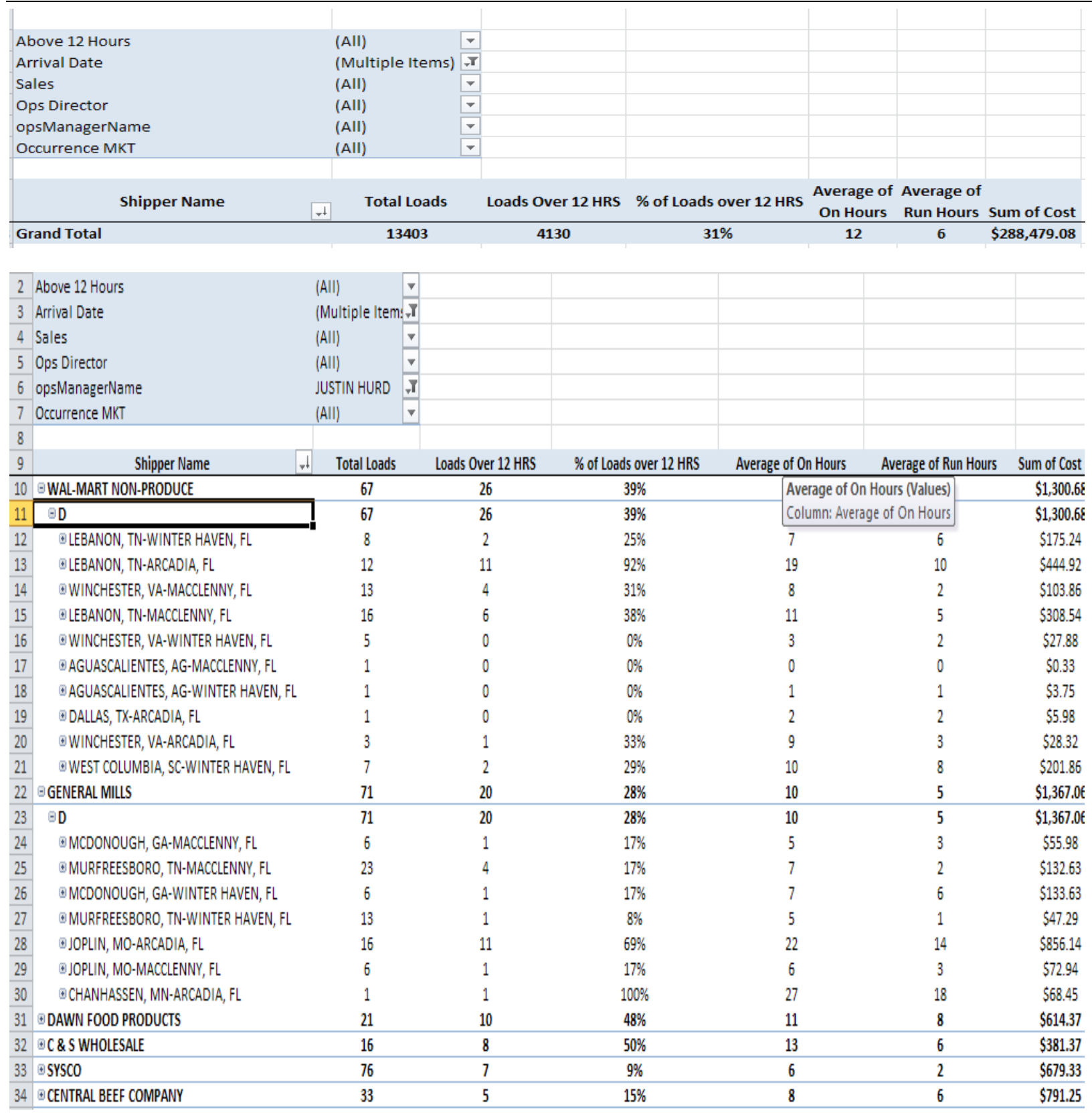




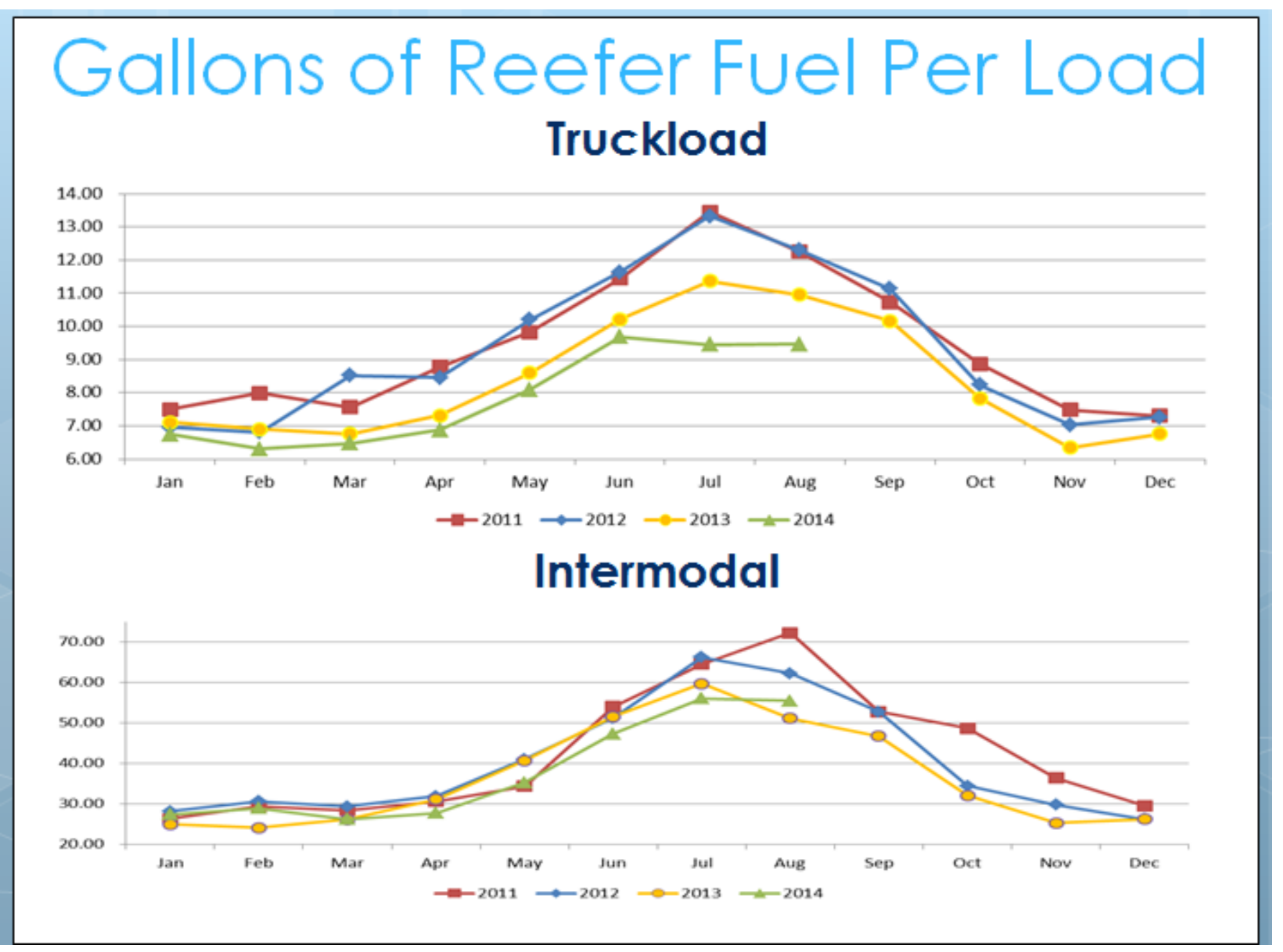




\section{Impact of Temperature Settings}

Percent of Reefer Burn by Temp Setting

\begin{tabular}{|l|r|r|r|r|r|r|r|r|r|r|r|r|}
\hline Category & \multicolumn{1}{|c|}{ May } & June & July & \multicolumn{1}{l|}{ August } & Sept & Oct & Nov & Dec & Jan & Feb & March & April \\
\hline Cycle at +5 & $46 \%$ & $55 \%$ & $58 \%$ & $52 \%$ & $44 \%$ & $35 \%$ & $30 \%$ & $25 \%$ & $26 \%$ & $26 \%$ & $28 \%$ & $37 \%$ \\
\hline Cycle at -1 & $49 \%$ & $56 \%$ & $60 \%$ & $56 \%$ & $48 \%$ & $38 \%$ & $30 \%$ & $27 \%$ & $26 \%$ & $27 \%$ & $29 \%$ & $39 \%$ \\
\hline Cycle at-10 & $66 \%$ & $73 \%$ & $76 \%$ & $74 \%$ & $65 \%$ & $53 \%$ & $44 \%$ & $37 \%$ & $36 \%$ & $36 \%$ & $40 \%$ & $54 \%$ \\
\hline Continuous Run & $100 \%$ & $100 \%$ & $100 \%$ & $100 \%$ & $100 \%$ & $100 \%$ & $100 \%$ & $100 \%$ & $100 \%$ & $100 \%$ & $100 \%$ & $100 \%$ \\
\hline
\end{tabular}

Gallons Used In 24 Hours

\begin{tabular}{|l|r|r|r|r|r|r|r|r|r|r|r|r|}
\hline Category & May & June & July & August & Sept & Oct & Nov & Dec & Jan & Feb & March & April \\
\hline Cycle at +5 & 9 & 11 & 11 & 10 & 9 & 7 & 6 & 5 & 5 & 5 & 5 & 7 \\
\hline Cycle at -1 & 9 & 11 & 12 & 11 & 9 & 7 & 6 & 5 & 5 & 5 & 6 & 8 \\
\hline Cycle at -10 & 13 & 14 & 15 & 14 & 12 & 10 & 8 & 7 & 7 & 7 & 8 & 10 \\
\hline Continuous Run & 19 & 19 & 19 & 19 & 19 & 19 & 19 & 19 & 19 & 19 & 19 & 19 \\
\hline
\end{tabular}

Cost of Reefer Burn at $\$ 4.00 /$ gal per 24 Hours

\begin{tabular}{|l|l|l|l|l|l|l|l|l|l|l|l|l|}
\hline Category & May & June & July & August & Sept & Oct & Nov & Dec & Jan & Feb & March & April \\
\hline Cycle at +5 & $\$ 35.4$ & $\$ 42.1$ & $\$ 44.4$ & $\$ 40.2$ & $\$ 34.1$ & $\$ 26.9$ & $\$ 22.7$ & $\$ 19.3$ & $\$ 19.8$ & $\$ 19.7$ & $\$ 21.7$ & $\$ 28.7$ \\
\hline Temp Setting of - & $\$ 37.7$ & $\$ 42.8$ & $\$ 46.1$ & $\$ 42.9$ & $\$ 37.0$ & $\$ 29.0$ & $\$ 23.1$ & $\$ 20.8$ & $\$ 20.3$ & $\$ 20.4$ & $\$ 22.1$ & $\$ 30.1$ \\
\hline Cycle at-10 & $\$ 50.4$ & $\$ 55.9$ & $\$ 58.7$ & $\$ 57.0$ & $\$ 49.9$ & $\$ 40.9$ & $\$ 33.7$ & $\$ 28.7$ & $\$ 27.3$ & $\$ 28.0$ & $\$ 30.4$ & $\$ 41.1$ \\
\hline Continuous Run & $\$ 76.8$ & $\$ 76.8$ & $\$ 76.8$ & $\$ 76.8$ & $\$ 76.8$ & $\$ 76.8$ & $\$ 76.8$ & $\$ 76.8$ & $\$ 76.8$ & $\$ 76.8$ & $\$ 76.8$ & $\$ 76.8$ \\
\hline
\end{tabular}

Source: Developed by case writer 